\title{
Determinants and Aspirants for Nurse Migration from Nepal: A Cross Sectional Study from Kathmandu
}

\author{
Sabika Munikarl and Kanchan Thapa ${ }^{2}$
}

${ }^{1}$ Om Health Campus, Gopikrishnanagar, Kathmandu, Nepal

${ }^{2}$ Safa Sunaulo Nepal, Anamnagar, Kathmandu, Nepal

\begin{abstract}
Introduction: Migration is the result of interplay of many factors, which guide the individual's decision to emigrate. Health workers tend to go where the working conditions are best. This study aims to identify the determinants and aspirants of nurse migration from Nepal.

Methods: A descriptive cross sectional study was conducted using self administered questionnaire. A semi structured questionnaire was administered to all nurses working at a private hospital who met the inclusion criteria.

Results: Majority of the participants were 20 to 30 years old (93.20\%), Hindu (86.5\%), Chhetri (35.1\%), unmarried (66.2\%), had completed intermediate level (58.1\%). Among the total respondents, 93.20\% intended to migrate to abroad and more than half of the respondent $(62.20 \%)$ preferred Australia as destination. The general factor provoking migration was poor nature of politics (98.6\%) followed by political instability $(90.5 \%)$ and non-availability of job $(90.5 \%)$. The major working condition and social factors provoking migration were occupational security in other country $(85.10 \%)$ and peer influence $(91.9 \%)$ respectively. The reasons for migration as mentioned by respondents were education $(59.50 \%)$ followed by better job opportunities (40.50\%), better living standard (21.60\%) and family and/or peer pressure $(8.10 \%)$.

Conclusions: The present study concluded that majority wanted to migrate and Australia was famous choices for nurses. Poor nature of politics, occupational security in other country and peer influence were factors for migration. The major purpose for migration was education.

Key words: aspirant; determinant; migration; nurse
\end{abstract}

Correspondence: Kanchan Thapa, Safa Sunaulo Nepal, Anamnagar, Kathmandu, Nepal. E-mail: kanchanraj3@gmail.com

DOI: http://dx.doi.org/10.3126/mjsbh.v18i2.22855

Submitted on: 2019-02-07

Accepted on: 2019-06-17

This work is licensed under creative common license:

http://creativecommons.org/licenses/by-nc-nd/4.0/ (C) MJSBH 2019 


\section{INTRODUCTION}

Migration is the spatial mobility that shows the change from one geographical location to another. Oxford dictionary defines migration as movement of people to a new area or country in order to find work or better living conditions. ${ }^{1}$ The term "Brain drain" is used when highly trained or qualified workers move from nation of origin to other nations usually for better pay or living conditions. ${ }^{2}$ Migration is the result of interplay of many factors, which motivate and guide the individual's decision to emigrate. Some of those factors are economic, cultural, social, political and legal forces. ${ }^{3}$

Human resources for health are one of the most important elements of the healthcare system of any country as the quality of delivering health services depends primarily on the performance of providers. However, health workers, like workers in all sectors, tend to go where the working conditions are best. Income is an important motivation for migration, but not the only one. Other reasons include: greater job satisfaction, career opportunities, the quality of management and governance, moving away from political conflicts, war, and the threat of violence in the workplace. ${ }^{4}$ Migration of health workforce is found throughout the world. ${ }^{5,6,7}$ However, every year many health workers migrate to developed world and majority consists of nurses from Nepal. ${ }^{8}$ In recent years, there is increasing trend of migration among nurses to developed countries. Hence, it is important to explore socio-economic factors and intend to migration among the Nepalese nurses.

\section{METHODS}

The study was conducted at a tertiary level private hospital at Lalitpur for a period of one month. A descriptive cross sectional study was conducted to identify the intent of migration and its contributing factors. All the 74 nurses working in the hospital were included in the study. A self-administered questionnaire was developed, and administered. The questionnaire consisted of sociodemographic information and questionnaire related to push and pull factors of migration. Approval for data collection was obtained from hospital authority and informed verbal consent was obtained from each participant before data collection. The collected data was analysed for descriptive statistics using SPSS Version 17.

\section{RESULTS}

Out of the total 74 nurses who participated in this study, most of them $(93.20 \%)$ were in age group 20 to 30 years. Majority of them $(86.50 \%)$ were Hindu. The highest number of respondents (35.10\%) belonged to Chhetri caste. More than half $(66.20 \%)$ were unmarried. More than half of them $(58.10 \%)$ had completed intermediate level and least $(2.70 \%)$ had completed masters level. Almost half of the respondents $(52.70 \%)$ were from Kathmandu valley.

More than half of the respondents $(58.10 \%)$ were not satisfied in their current job in which majority of them $(86.50 \%)$ were not satisfied financially.

Table 1. Distribution of Socio-demographic characteristics of respondents $(n=74)$

\begin{tabular}{|c|c|c|c|}
\hline SN & Characteristics & Categories & Number (\%) \\
\hline \multirow[t]{2}{*}{1} & \multirow[t]{2}{*}{ Age (in years) } & $20-30$ & $69(93.20 \%)$ \\
\hline & & $30-40$ & $5(6.80 \%)$ \\
\hline \multirow[t]{3}{*}{2} & \multirow[t]{3}{*}{ Religion } & Hindu & $64(86.50 \%)$ \\
\hline & & Buddhist & $6(8.10 \%)$ \\
\hline & & $\begin{array}{l}\text { Christian and } \\
\text { others }\end{array}$ & $70(5.50 \%)$ \\
\hline \multirow[t]{5}{*}{3} & \multirow[t]{5}{*}{ Ethnicity } & Brahmin & $10(13.50 \%)$ \\
\hline & & Chhetri & $26(35.10 \%)$ \\
\hline & & Newar & $22(29.70 \%)$ \\
\hline & & Gurung & $6(8.10 \%)$ \\
\hline & & Others & $10(13.50 \%)$ \\
\hline \multirow[t]{2}{*}{4} & \multirow[t]{2}{*}{ Marital status } & Married & $25(33.80 \%)$ \\
\hline & & Unmarried & $49(66.20 \%)$ \\
\hline \multirow[t]{3}{*}{5} & \multirow[t]{3}{*}{$\begin{array}{l}\text { Educational } \\
\text { level }\end{array}$} & Intermediate & $43(58.10 \%)$ \\
\hline & & Bachelor & $29(39.20 \%)$ \\
\hline & & Master & $2(2.70 \%)$ \\
\hline \multirow[t]{2}{*}{6} & \multirow{2}{*}{$\begin{array}{l}\text { Permanent } \\
\text { residence }\end{array}$} & Kathmandu & $39(52.70 \%)$ \\
\hline & & Out of valley & $35(37.30 \%)$ \\
\hline
\end{tabular}


Table 2. Distribution of satisfaction status and perceived factors for migration by respondents $(n=74)$

\begin{tabular}{|c|c|c|c|}
\hline SN & Characteristics & Categories & Number (\%) \\
\hline \multirow[t]{2}{*}{1} & \multirow[t]{2}{*}{ Job satisfaction } & Yes & $\begin{array}{l}30 \\
(40.50 \%)\end{array}$ \\
\hline & & No & $\begin{array}{l}43 \\
(58.10 \%)\end{array}$ \\
\hline \multirow[t]{2}{*}{2} & \multirow[t]{2}{*}{$\begin{array}{l}\text { Financial } \\
\text { satisfaction }\end{array}$} & Yes & $\begin{array}{l}7 \\
(9.50 \%)\end{array}$ \\
\hline & & No & $\begin{array}{l}64 \\
(86.50 \%)\end{array}$ \\
\hline \multirow[t]{2}{*}{3} & \multirow{2}{*}{$\begin{array}{l}\text { Area of highest } \\
\text { financial } \\
\text { satisfaction }\end{array}$} & Rural & $\begin{array}{l}31 \\
(41.90 \%)\end{array}$ \\
\hline & & Urban & $\begin{array}{l}34 \\
(45.90 \%)\end{array}$ \\
\hline \multirow[t]{3}{*}{4} & \multirow{3}{*}{$\begin{array}{l}\text { Perceived } \\
\text { organisation } \\
\text { with high } \\
\text { financial } \\
\text { incentives* }\end{array}$} & $\begin{array}{l}\text { Government } \\
\text { organisation }\end{array}$ & $\begin{array}{l}23 \\
(31.40 \%)\end{array}$ \\
\hline & & $\begin{array}{l}\text { Private } \\
\text { organisation }\end{array}$ & $\begin{array}{l}3 \\
(4.10 \%)\end{array}$ \\
\hline & & NGO/ INGO & $\begin{array}{l}59 \\
(79.90 \%)\end{array}$ \\
\hline \multirow[t]{5}{*}{5} & \multirow{5}{*}{$\begin{array}{l}\text { Perceived } \\
\text { foreign country } \\
\text { with highest } \\
\text { financial } \\
\text { satisfaction* }\end{array}$} & China & $\begin{array}{l}1 \\
(1.40 \%)\end{array}$ \\
\hline & & $\begin{array}{l}\text { Other Asian } \\
\text { country }\end{array}$ & $\begin{array}{l}1 \\
(1.40 \%)\end{array}$ \\
\hline & & USA & $\begin{array}{l}30 \\
(40.50 \%)\end{array}$ \\
\hline & & Europe & $\begin{array}{l}12 \\
(16.20 \%)\end{array}$ \\
\hline & & Australia & $\begin{array}{l}46 \\
(62.20 \%)\end{array}$ \\
\hline
\end{tabular}

*multiple choices answers are possible

Less than half of the respondent perceived of highest financial satisfaction working in rural areas. Similarly, majority of respondent (79.90\%) perceived NGOs and INGOs as having highest financial incentives. More than half of the respondent (62.20\%) perceived Australia as having highest financial satisfaction.

Table 3 depicts the factors influencing intent to change job and migrate. The general factors provoking migration were political instability of country $(90.50 \%)$, bad nature of politician (98.60\%), non-freedom of expression (73.00\%),
Table 3. Distribution of factors influencing intend to change the job and migrate by respondents $(n=74)$

\begin{tabular}{|c|c|c|c|}
\hline SN & Characteristics & $\begin{array}{l}\text { Number } \\
\text { (n) }\end{array}$ & $\begin{array}{l}\text { Percentage } \\
(\%)\end{array}$ \\
\hline & \multicolumn{3}{|c|}{ Influence of country's status } \\
\hline 1 & $\begin{array}{l}\text { Political instability of } \\
\text { country }\end{array}$ & 67 & $90.50 \%$ \\
\hline 2 & $\begin{array}{l}\text { Bad nature of } \\
\text { politician }\end{array}$ & 73 & $98.60 \%$ \\
\hline 3 & $\begin{array}{l}\text { Non freedom of } \\
\text { expression }\end{array}$ & 54 & $73.00 \%$ \\
\hline 4 & Corruption in country & 66 & $89.20 \%$ \\
\hline \multirow[t]{2}{*}{5} & Non availability of job & 67 & $90.50 \%$ \\
\hline & \multicolumn{3}{|c|}{ Outlook on working condition } \\
\hline 6 & $\begin{array}{l}\text { Lack of Occupational } \\
\text { security }\end{array}$ & 37 & $50.00 \%$ \\
\hline 7 & $\begin{array}{l}\text { Occupational security } \\
\text { in other country }\end{array}$ & 63 & $85.10 \%$ \\
\hline 10 & Provision of promotion & 51 & $68.90 \%$ \\
\hline \multirow[t]{2}{*}{11} & $\begin{array}{l}\text { Provision of in service } \\
\text { training and workshop }\end{array}$ & 22 & $29.70 \%$ \\
\hline & \multicolumn{3}{|c|}{ Family and Social support for Migration } \\
\hline 13 & $\begin{array}{l}\text { Family support to } \\
\text { migrate }\end{array}$ & 66 & $89.20 \%$ \\
\hline 14 & $\begin{array}{l}\text { Family support on } \\
\text { current job }\end{array}$ & 62 & $83.80 \%$ \\
\hline 15 & $\begin{array}{l}\text { Responsibility towards } \\
\text { family }\end{array}$ & 61 & $82.40 \%$ \\
\hline 16 & $\begin{array}{l}\text { Family influence on } \\
\text { migration }\end{array}$ & 59 & $79.70 \%$ \\
\hline 17 & Peer influence & 68 & $91.90 \%$ \\
\hline
\end{tabular}

corruption (89.20\%) and non-availability of job $(90.50 \%)$. Similarly those working condition influencing migration were lack of occupational security $(50 \%)$, occupational security in other countries $(85.10 \%)$, lack of promotion $(68.90 \%)$, job dissatisfaction $(62.40 \%)$ and lack of provision of in-service training and workshop $(29.70 \%)$.

The social factors for influencing migration were family support $(89.20 \%)$, family support on current job $(83.80 \%)$, responsibility towards family $(82.40 \%)$, and family influence on migration 
Table 4. Distribution of Intent to and factors for migration among the respondents $(n=74)$

\begin{tabular}{|c|c|c|c|}
\hline SN & Characteristics & Categories & $\begin{array}{l}\text { Number } \\
(\%)\end{array}$ \\
\hline \multirow[t]{2}{*}{1} & \multirow{2}{*}{$\begin{array}{l}\text { Intend to change } \\
\text { current job }\end{array}$} & Yes & $51(68.90 \%)$ \\
\hline & & No & $23(31.10 \%)$ \\
\hline \multirow[t]{3}{*}{2} & \multirow[t]{3}{*}{$\begin{array}{l}\text { Choice of new } \\
\text { organization* }\end{array}$} & $\begin{array}{l}\text { Government } \\
\text { organisation }\end{array}$ & $27(36.50 \%)$ \\
\hline & & $\begin{array}{l}\text { Private } \\
\text { organisation }\end{array}$ & $2(2.70 \%)$ \\
\hline & & NGO/ INGO & $31(41.90 \%)$ \\
\hline \multirow[t]{5}{*}{3} & \multirow[t]{5}{*}{$\begin{array}{l}\text { Reason of } \\
\text { changing } \\
\text { organisation* }\end{array}$} & $\begin{array}{l}\text { Inadequate } \\
\text { financial } \\
\text { incentives }\end{array}$ & $34(45.90 \%)$ \\
\hline & & $\begin{array}{l}\text { Poor working } \\
\text { condition }\end{array}$ & $12(16.20 \%)$ \\
\hline & & $\begin{array}{l}\text { Lack of career } \\
\text { development }\end{array}$ & $26(35.10 \%)$ \\
\hline & & $\begin{array}{l}\text { Excessive } \\
\text { workload }\end{array}$ & $6(8.10 \%)$ \\
\hline & & Others & $1(1.40 \%)$ \\
\hline \multirow[t]{2}{*}{4} & \multirow{2}{*}{$\begin{array}{l}\text { Intent to migrate } \\
\text { abroad }\end{array}$} & Yes & $69(93.20 \%)$ \\
\hline & & No & $4(5.40 \%)$ \\
\hline \multirow[t]{2}{*}{5} & \multirow{2}{*}{$\begin{array}{l}\text { Desire of } \\
\text { migrate since kid }\end{array}$} & Yes & $28(37.80 \%)$ \\
\hline & & No & $43(58.10 \%)$ \\
\hline \multirow[t]{2}{*}{6} & \multirow[t]{2}{*}{$\begin{array}{l}\text { Time for starting } \\
\text { of intent to } \\
\text { migrate }\end{array}$} & $\begin{array}{l}\text { Before } \\
\text { medical } \\
\text { education }\end{array}$ & $26(35.10 \%)$ \\
\hline & & $\begin{array}{l}\text { After medical } \\
\text { education }\end{array}$ & $44(59.50 \%)$ \\
\hline \multirow[t]{4}{*}{7} & \multirow{4}{*}{$\begin{array}{l}\text { Plan to migrate } \\
\text { (in years) }\end{array}$} & Within a year & $22(29.70 \%)$ \\
\hline & & 1-3 year & $30(40.50 \%)$ \\
\hline & & 3-5 years & $12(16.20 \%)$ \\
\hline & & 5-10 years & $6(8.10 \%)$ \\
\hline \multirow[t]{4}{*}{8} & \multirow{4}{*}{$\begin{array}{l}\text { Purpose of } \\
\text { migrating } \\
\text { abroad* }\end{array}$} & $\begin{array}{l}\text { Further } \\
\text { education }\end{array}$ & $44(59.50 \%)$ \\
\hline & & $\begin{array}{l}\text { Better job } \\
\text { opportunities }\end{array}$ & $30(40.50 \%)$ \\
\hline & & $\begin{array}{l}\text { Family and/ } \\
\text { or peer } \\
\text { pressure }\end{array}$ & $6(8.10 \%)$ \\
\hline & & $\begin{array}{l}\text { Better living } \\
\text { standard }\end{array}$ & $16(21.60 \%)$ \\
\hline
\end{tabular}

*multiple choices answers are possible
$(79.70 \%)$ and peer influence $(91.90 \%)$

Table 4 illustrates the intent to migrate among nurses. Among the total respondents, intention of changing current job was expressed by $68.90 \%$ of respondents. They preferred NGO/ INGO (41.90\%) as new organisation followed by government organisation $(36.50 \%)$ and private organisation $(2.70 \%)$.

The major reason for changing organisation as mentioned by respondent was inadequate financial incentives $(45.90 \%)$ followed by lack of career development $(35.10 \%)$, poor working condition $(16.20 \%)$, excessive workload $(8.10 \%)$ and others $(1.40 \%)$.

Among the total respondents, $93.20 \%$ intended to migrate to abroad. Among those who had intention of migration, only $37.80 \%$ of respondents had desire to migrate since kid. More than half of the respondent $(59.50 \%)$ had intention of migrating abroad after starting their medical education. Among those respondent willing to migrate, $40.50 \%$ have intention of migrating within 1-3 years followed by migrating within a year $(29.70 \%), 3-5$ years $(16.20 \%)$ and $5-10$ years $(8.10 \%)$. More than half of respondent intending to migrate abroad mentioned further education as purpose of migration (59.50\%) followed by better job opportunities $(40.50 \%)$, better living standard $(21.60 \%)$ and family and/or peer pressure $(8.10 \%)$.

\section{DISCUSSION}

The present study was conducted to explore the different socio demographic determinants for aspiration of migration among Nepalese nurses working in a private hospital of Kathmandu. Transfer of human resources for health can be considered as international trade as well as an opportunity to skill human resources through international market. ${ }^{9}$ The present study explores the migratory attitudes among the young nurses in Nepal. More than nine nurses among 10 were recruited in present study and nearly equal proportion were from Hindu community. Two third were married and nearly six among 10 had only completed intermediate level of education. One 
among two were out of the valley and currently working in Kathmandu. Another research done in Nepal which also explores the migration intention showed that $44.3 \%$ of respondents belonged to age group 26 to 30 years; $91.2 \%$ were Hindu; $39.9 \%$ were Brahmin, $62.3 \%$ were unmarried and $34.6 \%$ had obtained bachelor degree. ${ }^{10}$

Job satisfaction is always considered as important factors for changing job and workplace. In the present study, nearly six among then 10 were not satisfied in their current job, the financial job satisfaction was one of the major reason. Nursing profession in Nepal has faced several challenges such as low nurse patient ratio, lack of physical facilities, non-conducive workplace environment, discriminatory laws. ${ }^{11}$ Nepal government also does not have appropriate policy for retaining health workforce at the country. However, the country has always faced shortage of workforce in health sector. ${ }^{11}$ Nurses think that they will be less satisfied working in rural Nepal. ${ }^{12}$ Similar experienced were found for other skilled health force. ${ }^{13}$ Nearly eight among 10 were interested to work in national and international nongovernmental organisation which they think to have high financial satisfaction. Another study conducted in Nepal found that the nurses preferred to work in government institution followed by NGOs and INGOs. ${ }^{14}$ This study revealed that the most chosen country for migration is Australia followed by USA and Europe which is similar to other studies which suggests the intended country to be Australia ${ }^{13-15}$ followed by UK and USA, ${ }^{15,16}$ which is contrary to study conducted in Poland in which the most preferred destination was Europe, followed by UK and USA. ${ }^{17}$ The medical graduates however intent to migrate to USA and $\mathrm{UK}^{3}$

Furthermore, political instability of country, poor nature of politics, non-freedom to express their views among people, corruption and nonavailability of job as per their education qualification were factors for migration intention among nurse. Another research conducted among nurses working abroad and Nepal depicted the push factor for migration were political conflict (64.0\%), lack of job (80.7\%), lack of career opportunity
(70.2\%). ${ }^{10}$ A qualitative study conducted among 15 Nepalese health professionals migrated to United Kingdom revealed better opportunities, stable political situation in UK to be major pull factors and corruption in Nepal to be push factor. ${ }^{13}$ However a study conducted among medical graduates in Pakistan depicted that political condition of country have least contribution to the decision to migrate. ${ }^{3}$

Likewise, one among two believed lack of occupation security was in country whereas majority believed to have occupational security in other countries. Other factors for migration intention was dissatisfaction, lack of promotion, lack of in-service trainings and workshops during their job tenure. Studies conducted in different parts of world concluded that very important pull factors in abroad were better job and career opportunity, better working condition and job satisfaction. $3,10,11,14,18$ A study conducted among Nepalese nurses working abroad revealed lack of training and educational opportunities, lack of job and career opportunities ranked as major causes of migration. ${ }^{2,13}$ In a focused group discussion during study conducted at Uganda, nurses revealed the dissatisfactions working in home country as too little pay, inadequate equipment and supplies, poor benefits, not enough public sector jobs and nurses treated badly. ${ }^{18}$

Social factors plays important role in life of human being. The important factor for migration intention was family support for applying abroad. A similar finding was depicted in a study conducted among nurses working in Nepal and abroad which depicted that family future security ${ }^{10,13}$ was a major push factor for migration. The other factors included that they have family support in current job, higher financial and other responsibility in their families, family member's influences on applying abroad were for migration aspiration. Likewise, peer pressure played vital role for migration aspiration. More than nine among ten reported to have influence from their peer to plan for migration abroad which is consistent with the findings of a qualitative study conducted in UK. ${ }^{13}$ 
Those who were working in current position also reported to change their job. More than $68 \%$ wanted to change their current job. More than four among 10 preferred INGO as their preferred choices whereas nearly three percentage wanted to join private hospitals. Those who were dissatisfied were due to low pay of hospitals, lack of career development, poor working condition and high workload.

Among the total respondents, more than 93\% wanted to migrate abroad which is similar to the findings of study conducted by Deressa and Azazh which was $91 \%{ }^{16}$ and study conducted at Uganda which was $70 \% .{ }^{18}$ However, a survey conducted by ILO depicted that only $41.9 \%$ of nurses wished to migrate abroad for further studies and $15.6 \%$ for work. ${ }^{14}$ The results are quite different among medical graduates which is $60.4 \%{ }^{3}, 53 \%{ }^{16}$ intended to train abroad for specialty. Nearly six among ten thought about migrating abroad after coming to nursing profession whereas more than $37 \%$ had their dream to migrate abroad since their kid. Recent years spent in their job might have created more desire to migrate those who have already spent more than three years were less likely to migrate.
The major attraction in abroad was for education purpose, better job opportunities and improved livening standards. Study of Lithuania states that the important factors for attracting health professionals are high salary, professional development, possibility to work in other cultures. ${ }^{19}$ However, Nepalese nurses considered these factors for migrating abroad. A systematic review conducted showed that there is difference between work related injuries among migrated and native nurses. Though, there was family support for migrating abroad less than one among ten felt about pressure of their family to migrate abroad.

\section{CONCLUSIONS}

The present study concluded that younger and unmarried nurses were mainly attracted to migrate. Job and financial satisfaction were factors for migration. Majority wanted to migrate and Australia was famous choices for nurses. Family support and peer pressure was main reason for intend to migrate. Majority developed migration aspiration after coming to medical profession.

To cite this article: Munikar S, Thapa K. Determinants and aspirants for nurse migration from Nepal: A cross sectional study from Kathmandu. MJSBH. 2019;18(2):22-8.

Conflict of Interest: None declared

\section{REFERENCES}

1. Oxford Dictionary. 2nd ed. Oxford University Press. 2014. Available from: https://en.oxforddictionaries.com/ definition/migration

2. Baral R, Sapkota S. Factors influencing migration among nepalese nurses. J Chitwan Med Coll. 2015;5(12):25-9. DOI: https://doi.org/10.3126/jcmc.v5i2.13151

3. Imran N, Azeem Z, Haider II, Amjad N, Bhatti MR. Brain Drain: Post Graduation Migration Intentions and the influencing factors among Medical Graduates from Lahore, Pakistan. BMC Res Notes. 2011;4(1):417.

DOI: https://doi.org/10.1186/1756-0500-4-417

4. Baral R. Factors Influencing Migration among Nepalese Nurses. J Chitwan Med Coll. 2015;5(12):25-9.

DOI: https://doi.org/10.3126/jcmc.v5i2.13151

5. Aluttis C, Bishaw T, Frank MW. The workforce for health in a globalised context- global shortages and international migration. Glob Health Action. 2014;7:1-7. 
DOI: https://doi.org/10.3402/gha.v7.23611

6. Kim B, Young S. Patterns and Influential factors of inter-regional migration of new and experienced nurses in 2011-2015. J Korean Acad Nurs. 2017;47(5):676-88.

DOI: https://doi.org/10.4040/jkan.2017.47.5.676

7. Kingma M. Nurses on the Move : A Global Overview. Health Serv Res. 2007;42(3):1281-98. DOI: https://doi.org/10.1111/j.1475-6773.2007.00711.x

8. Adhikari R. Vacant hospitals and under-employed nurses : a qualitative study of the nursing workforce management situation in Nepal. Health Policy Plan. 2015;30:289-97.

DOI: https://doi.org/10.1093/heapol/czu009

9. Aiken LH, Buchan J, Sochalski J, Nichols B, Powell M. Trends In International Nurse Migration. Health Aff. 2004;23(3):69-77.

DOI: https://doi.org/10.1377/hlthaff.23.3.69

10. Thapa B, Shrestha K. Factors Influencing Brain Drain among Nepalese Nurses. Kathmandu Univ Med J. 2017;57(1):35-9.

11. Dewan P. Human Resources for Health ( HRS ) Issues of Nursing Professionals : A Perspective from NAN. Nurs J Nepal. 2014;1(1):1-4.

12. Chadi A, Hetschko C. The Magic of the New : How Job Changes Affect Job Satisfaction Adrian Chadi, Clemens Hetschko. IAAEU Discuss Pap Ser Econ. 2014;(05).

13. Sapkota TN, Teijlingen E Van, Padam P, Care S. Nepalese health workers' migration to the United Kingdom: A qualitative study. Heal Sci J. 2014;8(1):57-74.

14. International Labor Organisation. Migration of health workers from Nepal. Kathmandu; 2017.

15. Silva NL De, Samarasekara K, Rodrigo C, Samarakoon L, Fernando SD, Rajapakse S. Why do doctors emigrate from Sri Lanka? A survey of medical undergraduates and new graduates. BMC Res Notes. 2014;7:918.

DOI: https://doi.org/10.1186/1756-0500-7-918

16. Deressa W, Azazh A. Attitudes of undergraduate medical students of Addis Ababa University towards medical practice and migration, Ethiopia. BMC Med Educ. 2012;12(1):1.

DOI: https://doi.org/10.1186/1472-6920-12-68

17. Szpakowski R, Zając PW, Dykowska G, Sienkiewicz Z, Augustynowicz A, Czerw A. Labour migration of Polish nurses: a questionnaire survey conducted with the Computer Assisted Web Interview technique. Hum Resour Health. 2016;14(S1):24.

DOI: https://doi.org/10.1186/s12960-016-0124-9

18. Nguyen L, Ropers S, Nderitu E, Zuyderduin A, Luboga S, Hagopian A. Intent to migrate among nursing students in Uganda: measures of the brain drain in the next generation of health professionals. Hum Resour Health. 2008;6:5.

DOI: https://doi.org/10.1186/1478-4491-6-5

19. Janusauskas A, Tumas V. Medical professional' emigration: causes and the consequences. Eur Sci J. 2014;10(8): 47-58. 